\title{
Intestinal intraepithelial lymphocytes have a promiscuous interleukin-8 receptor
}

\author{
A I Roberts, M Bilenker, E C Ebert
}

\begin{abstract}
Background-Human intraepithelial lymphocytes (IELs), predominantly $T$ cells of the $\mathrm{CD8}^{+} \mathrm{CD} \mathrm{RRO}^{+}$phenotype that are situated between epithelial cells, have a chemotactic response to the $\alpha$-chemokines, IL-8 and GRO, and the $\beta$-chemokine, and the protein termed regulated on activation, normal $T$ cell expressed and secreted (RANTES).
\end{abstract}

Aim-To evaluate the specificity of the IL-8 receptor on IELs.

Methods-Specificity was determined by the degree of desensitisation of the IL-8 response caused by each chemokine and the degree of inhibition of IL-8 binding to the cell.

Results-IELs migrated towards two additional $\beta$ chemokines, macrophage inflammatory protein-1 and monocyte chemotactic protein (MCP). All chemokines inhibited IL-8 induced chemotaxis and calcium ion mobilisation by IELs, with IL-8 having the greatest effect and MCP the least. In addition, specific binding of radiolabelled IL-8 to IELs was reduced by each of the five chemokines in cold competition experiments, whereas only GRO and IL-8 itself displaced ${ }^{125}$ I-IL8 from receptors on peripheral blood mononuclear cells.

Conclusions-The IL-8 responsiveness of IELs is desensitised by chemokines of both the $\alpha$ and $\beta$ families, and this is likely to occur by the binding of the chemokines to common receptors.

(Gut 1997; 40: 333-338)

Keywords: lymphocytes, intraepithelial, interleukin-8 receptor, chemokines, chemotaxis.

Interleukin 8 (IL-8), a proinflammatory cytokine with molecular mass of about $8 \mathrm{kDa}$, is a chemoattractant for many cell types, including neutrophils, basophils, peripheral blood $\mathrm{T}$ lymphocytes, natural killer cells, and jejunal intraepithelial lymphocytes (IELs) ${ }^{1-6}$ It is produced by monocytes, neutrophils, hepatocytes, and intestinal epithelial cells after stimulation with cytokines such as IL-1 and TNF $\alpha{ }^{7-12}$ Along with other soluble factors, IL-8 coordinates the inflammatory response to injury.

IL-8 is a member of a class of proteins called chemokines that are grouped into two families depending on the sequence of a common conserved region: the sequence $\mathrm{C}-\mathrm{X}-\mathrm{C}$ is characteristic of the $\alpha$-chemokines, whereas the sequence $\mathrm{C}-\mathrm{C}$ identifies the $\beta$ family. The $\alpha$-chemokines, including IL- 8 and GRO, are potent chemoattractants for neutrophils and $T$ cells, but not monocytes, whereas the $\beta$-chemokines, such as monocyte chemotactic protein (MCP), macrophage inflammatory protein (MIP), and the protein termed "regulated upon activation, normal $\mathrm{T}$ cell expressed and secreted" (RANTES) attract monocytes and $T$ cells, but not neutrophils. ${ }^{13-22}$ Five different chemokine receptors have been identified: (1) the IL-8 RA receptor which binds IL-8 at high affinity (Kd $2 \mathrm{nM}$ ) and GRO at low affinity (Kd $450 \mathrm{nM}$ ); (2) the IL-8 RB receptor which binds IL-8 and GRO at high affinity (Kd $2 \mathrm{nM})^{17}$; (3) the RANTES/ MIP-1 $\alpha$ receptor which binds the first at high affinity (Kd of $0.7 \mathrm{nM}$ ) and the second at lower affinity (Kd $35 \mathrm{nM}$ ); (4) the MCP-1 receptor which binds only this chemokine at $\mathrm{Kd} 0.5$ $n M,{ }^{19}$ and (5) the erythrocyte $C K$ receptor, which binds both $\alpha$-chemokines and $\beta$ chemokines except MIP-1 $\alpha$ and MIP-1 $\beta$ at high affinity $(\mathrm{Kd} 5 \mathrm{nM}) .^{21}$

The IELs, predominantly $T$ cells of the $\mathrm{CD}^{+} \mathrm{CD} 45 \mathrm{RO}^{+}$phenotype that are situated between epithelial cells, migrate toward IL-8, GRO, and RANTES, whereas lamina propria lymphocytes (LPLs), in which the $\mathrm{CD}^{+} \mathrm{CD}^{4} 5 \mathrm{RO}^{+} \mathrm{T}$ cell phenotype predominates, show less chemotaxis. ${ }^{56}$ By contrast, among peripheral blood $T$ cells, the $\mathrm{CD}^{+} \mathrm{CD} 45 \mathrm{RO}^{+}$phenotype shows preferential attraction for RANTES but not IL-8. ${ }^{22}$ Another unusual feature of the IEL response to chemokines is that calcium ion mobilisation due to release of internal stores is variable (greatest with IL-8 and absent with GRO), and does not correlate with the migratory response. ${ }^{5}$ Preliminary experiments have also shown that IELs become desensitised to both IL-8 and RANTES on exposure to either individual chemokine, suggesting a receptor that can bind both $\alpha$ and $\beta$ chemokines, perhaps similar to the promiscuous chemokine receptor on erythrocytes. ${ }^{5}$ This, too, contrasts with peripheral blood $\mathrm{T}$ cells, which have exclusive receptors for each family of chemokines.

To determine the nature of the chemokine receptor(s) on IELs, this study measured the responsiveness of IELs, LPLs, and PBMCs to the $\alpha$ - and $\beta$-chemokines through chemokine induced cell stimulation, as detected by calcium ion mobilisation and chemotaxis. The specificity of the IL-8 receptor on IELs was examined by determining which chemokines compete with IL- 8 for binding to the receptor and which ones can desensitise the cells to subsequent IL-8 stimulation. 


\section{Methods}

\section{Isolation of lymphocytes}

IELs were separated from jejunal mucosa obtained from healthy subjects undergoing gastric bypass operations for morbid obesity. Briefly, the minced mucosa was treated for 30 minutes with $1 \mathrm{mM}$ dithiothreitol at $37^{\circ} \mathrm{C}$ followed by three 45 minute treatments with $0.75 \mathrm{mM}$ EDTA in a shaking water bath at $37^{\circ} \mathrm{C}$ and the supernatant cells were collected. After purification by a Percoll density gradient, IEL preparations were over $90 \%$ lymphocytes that were $94 \pm 5 \% \mathrm{CD}^{+}$and $89 \pm 2 \% \mathrm{CD}^{+}$. For all experiments, IELs were first incubated with IL-2 $(10 \mathrm{U} / \mathrm{ml}$; Amgen, Thousand Oaks, CA, USA) for 72 hours as this increased IL-8 binding.

To isolate LPLs, the treated tissue received three more 45 minute incubations with EDTA, and the released cells were discarded. The remaining tissue was digested for three hours at $37^{\circ} \mathrm{C}$ in $20 \mathrm{U} / \mathrm{ml}$ collagenase and $0.01 \%$ deoxyribonuclease, then pressed through a wire mesh sieve to free any trapped cells. Purification on a Percoll density gradient yielded LPLs that were 55(SD 10)\% CD4 ${ }^{+}$, 35(SD 11)\% CD8 ${ }^{+} .5$

Peripheral blood mononuclear cells (PBMCs) were isolated from whole blood by Ficoll density gradient centrifugation.

\section{Migration assay}

The multiwell chemotaxis chamber of Boyden was used to measure lymphocyte migration in response to various factors. The upper and lower chambers were separated by a polyvinylpyrrolidone-free polycarbonate membrane with $5 \mu \mathrm{m}$ pores. Lymphocytes $\left(1 \times 10^{5} / 0.05 \mathrm{ml}\right)$ were placed in the upper chambers and various concentrations of purified recombinant human IL-8, GRO, RANTES, MCP-1, and MIP-1 $\alpha$ ( $R$ and D Systems, Minneapolis, MN, USA) were added to the lower chambers in duplicate. After a four hour incubation at $37^{\circ} \mathrm{C}$, the apparatus was kept at $4^{\circ} \mathrm{C}$ overnight to release lymphocytes bound to the underside of the membrane. After disassembly, the number of lymphocytes in each lower chamber was counted. After gently wiping the upper surface of the membrane to remove any adherent lymphocytes, the membrane was fixed in $70 \%$ ethanol, stained with toluidine blue, and then examined by light microscopy to verify that the lower surface was free of cells. Only viable lymphocytes migrated through the membrane, as determined by trypan blue exclusion.

\section{Calcium ion mobilisation studies}

Lymphocytes were loaded with Fura-2 AM (1 $\mu \mathrm{g} / \mathrm{ml}$, Molecular Probes, Eugene, OR, USA) for 20 minutes at $37^{\circ} \mathrm{C}$, washed, resuspended to $1-2 \times 10^{6} / \mathrm{ml}$, and placed on ice. After warming for five minutes, a $3 \mathrm{ml}$ sample was transferred to a polystyrene cuvette. Fluorescence was monitored in a fluorescence spectrophotometer for five minutes after the addition of each cytokine using an excitation wavelength of 340 or $380 \mathrm{~nm}$ while monitoring an emission wavelength of $510 \mathrm{~nm}$. Ionomycin $\left(1 \times 10^{-6} \mathrm{M}\right)$ was added as a positive control. Changes in cytoplasmic free calcium ion concentration $\left(\left[\mathrm{Ca}^{2+}\right]_{\mathrm{i}}\right)$ were calculated as a percentage of maximal fluorescence, with the dye fully chelated by the addition of ionomycin.

\section{Chemokine binding}

Cells $\left(4-5 \times 10^{6} / 0 \cdot 2 \mathrm{ml}\right)$ were incubated for $90 \frac{\bar{c}}{7}$ minutes on ice in siliconised polypropylene $\stackrel{\Phi}{\Omega}$ tubes with various concentrations $\left(10^{-11}\right.$ to $10^{-8} \mathrm{M}$ ) of ${ }^{125}$ I-labelled IL-8 (DuPont-NEN, $\vec{\circ}$ Wilmington, DE, USA) combined with various concentrations of an unlabelled chemokine in $\vec{\omega}$ binding medium, consisting of RPMI $1640 \stackrel{\circ}{\circ}$ with $10 \mathrm{mM}$ HEPES and $1 \%$ bovine serum albumin (BSA), $\mathrm{pH} 7 \cdot 4$. The incubation of period commenced with the addition of the $\omega$ cells to the reaction mixture and was terminated by the separation of the cells from this mixture by a density gradient. To accomplish this separation, the cell suspension was layered $\vec{z}$ over a $0.2 \mathrm{ml}$ cushion of ice cold Percoll diluted to $20 \%$ in binding medium in a $400 \mu l$ poly- $\frac{\rho}{\partial}$ ethylene microfuge tube, then centrifuged at $\overrightarrow{0}$ $12000 \mathrm{~g}$ for three minutes. The tubes were snap frozen in liquid nitrogen and the tips were cut off. The radioactivity in the tips containing the cell pellet ("bound") and that remaining in the reaction mixture in the tube ("free") were counted. The amount of specifically bound $\stackrel{\circ}{\triangleright}$ labelled peptide was calculated from known $\overrightarrow{\vec{D}}$ standards as the difference between total $\frac{0}{3}$ and non-specifically bound radioligand. Non- $\vec{T}$ specific binding was measured in the presence $\frac{F}{0}$ of $10^{-6} \mathrm{M}$ unlabelled ligand. ${ }^{23-25}$

\section{Statistical analysis}

For each set of data, a mean and SD were $\frac{\delta}{3}$ calculated. Pairs of data sets were analysed by Student's $t$ test for paired or independent variables.

\section{Results}

Migration of IELs, LPLs, and PBMCs to chemokines

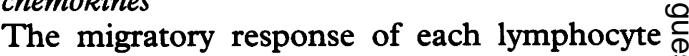
type to the various chemokines was tested in $\stackrel{?}{+}$ the Boyden multiwell system after stimulation 0 with IL-2 for three days (Fig 1). The spon- $\frac{O}{D}$ taneous migration to medium alone, averaging $\stackrel{\square}{\triangle}$

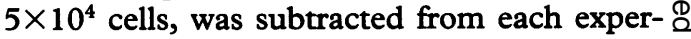
imental value. Chemokines were added to the lower chambers at concentrations of 1 to $1000 \Omega$ $\mathrm{nM}$. The migratory response of IELs to IL-8응 depended on the concentration of chemokine, reaching a maximum of 18750 cells at $1000 \stackrel{?}{\rightleftharpoons}$ $\mathrm{nM}$. This exceeded the similarly profiled doseresponse of LPLs $(p<0.01)$, but was equivalent to the maximal response of PBMCs, which occurred at $100 \mathrm{nM}$. The responses to GRO, also an $\alpha$-chemokine, showed a different pattern: the maximal response of IELs, occurring at $10 \mathrm{nM} \mathrm{GRO}$, was greater than the 
maximum for PMBCs $(\mathrm{p}<0.01)$, occurring at $100 \mathrm{nM}$, but no different from the LPL response, peaking at $10 \mathrm{nM}$. RANTES induced a greater peak response by IELs than LPLs or PBMCs $(p<0.05$; occurring at 1000 ,
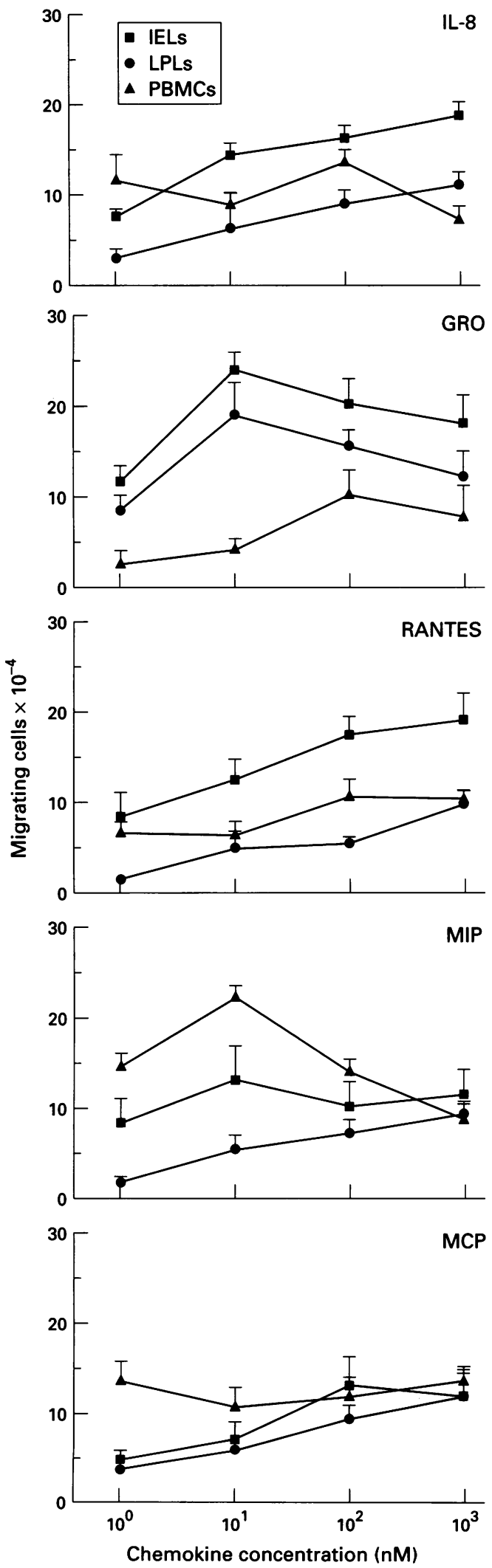

Figure 1: IELs (), LPLs (O), and PBMCs (A) were tested for migration toward IL-8, GRO, RANTES, $M I P-1$, and MCP with concentrations ranging from 1 to $1000 \mathrm{nM}$ in six experiments. The number of cells migrating toward medium alone was subtracted from each result. Bars are SD.
1000, and $100 \mathrm{nM}$, respectively). MIP, in contrast, attracted more PBMCs than IELs or LPLs $(p<0.05$ with peak responses at 10,10 , and $1000 \mathrm{nM}$, respectively), whereas MCP produced similar migratory responses in all three lymphocyte types.

Calcium mobilisation by IELs, LPLs, and PBMCs

Cell stimulation in response to chemokine exposure was determined by changes in the cytoplasmic concentration of the secondary messenger, divalent calcium ion $\left[\mathrm{Ca}^{2+}\right]$; as measured by changes in fluorescence emission of Fura-2 loaded cells after the addition of chemokine. IL- 8 induced the largest increase in $\left[\mathrm{Ca}^{2+}\right]_{\mathrm{i}}$ in IELs, whereas RANTES had a smaller effect: $13 \cdot 3$ (SD 0.5$) \%$ and $8 \cdot 7$ (SD $0 \cdot 1) \%$ of maximum respectively ( $n=7$; Fig 2$)$. Little calcium flux occurred with the other chemokines: $0 \cdot 7$ (SD 0.7$) \%$ with GRO, 0.6 (SD $0.6) \%$ with $\mathrm{MIP}$, and 1.5 (SD 0.9$) \%$ with MCP. LPLs, in contrast, showed negligible calcium mobilisation with any chemokine. PBMCs, like IELs, showed the greatest influx with IL-8 (8.6(SD 1.9)\%), a lesser response to RANTES (3.6(SD 2.9)\%) and MIP (3.2(SD $0.5) \%$, and little response to GRO or MCP $(1 \cdot 8(\mathrm{SD} 1 \cdot 3) \%$ and $1 \cdot 1(\mathrm{SD} 1 \cdot 0) \%$, respectively) $(\mathrm{n}=3)$.

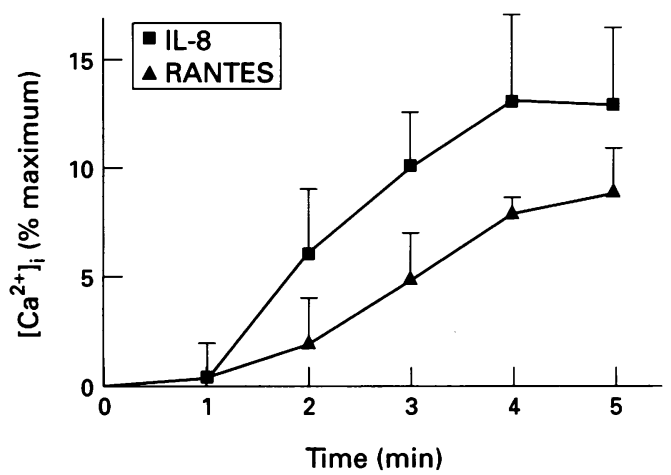

Figure 2: Changes in cytoplasmic free calcium ion concentration as measured by fluorescence emission from Fura-2 loaded IELs. IL-8 (-) or RANTES $(\boldsymbol{\Delta})$ were added at $1000 \mathrm{nM}$ at time $=0$. Values are percentages of maximal fluorescence obtained on the addition of ionomycin, for seven experiments. Bars are $S D$.

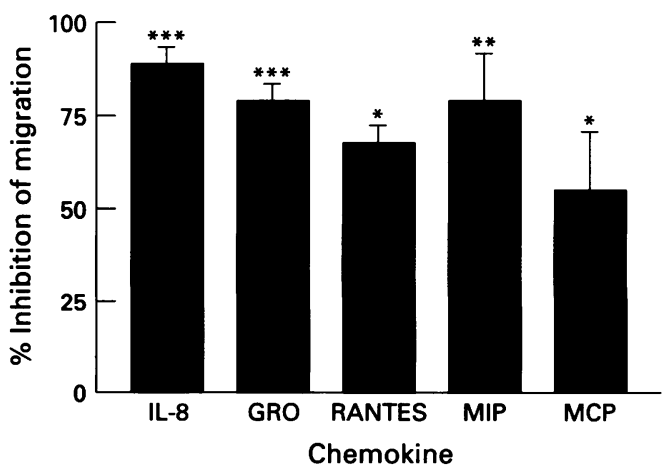

Figure 3: IEL were cultured with IL-2 for two days with or without each chemokine listed on the $x$ axis, and then tested for their migratory response to IL-8 (1000 $\mathrm{nM})$. All chemokines desensitised IEL chemotaxis to IL-8 in eight experiments. Bars are SD. ${ }^{\star} p<0 \cdot 05 ;{ }^{\star *} p<0 \cdot 01$; $\star_{* *}<0.001$. 
Desensitisation experiments

The ability of IELs to become desensitised to IL-8 stimulation by each of the chemokines was tested in two ways. Firstly, to measure desensitisation of the chemotactic response,

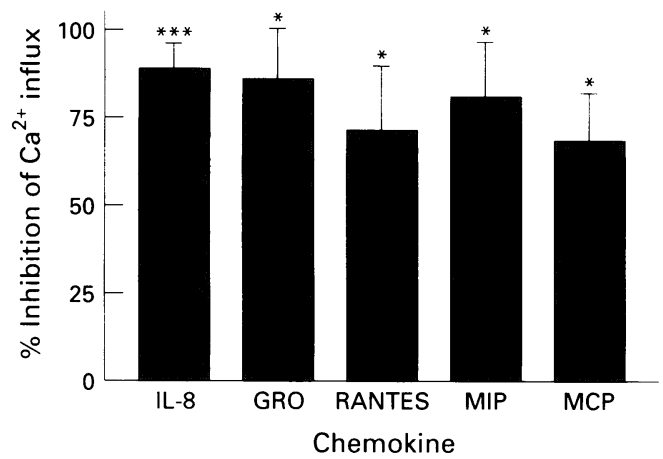

Figure 4: IELs were cultured for two days with IL-2, loaded with Fura-2, and exposed for 10 minutes to each chemokine listed on the $x$ axis to induce desensitisation. Then cells were tested for calcium mobilisation in response to IL-8 (1000 $n M)$. All chemokines desensitised IELs to IL-8 in six experiments. Bars are $S D .{ }^{\star} p<0 \cdot 05 ;{ }^{\star \star *} p<0 \cdot 001$.

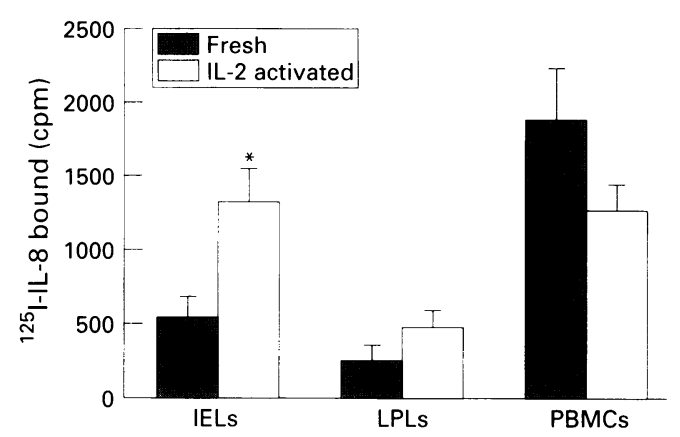

Figure 5: IELs, LPLs, and PBMCs, used fresh or after $I L-2$ activation, were tested for specific binding of IL-8. Cells were incubated on ice with ${ }^{125} I-I L-8(10 \mathrm{nM})$ in the absence or presence of unlabelled IL-8 (1000 nM) (nonspecific binding), and radioactivity associated with the cell pellet determined. Specific binding was calculated as the difference between total and non-specific binding. Values represent the mean (SD) for six experiments.
IELs were cultured with IL-2 with or without each chemokine (1000 nM). After 72 hours, the cells were washed and tested for their migratory response to $1000 \mathrm{nM}$ IL-8 (Fig 3). Pre-exposure to chemokines from either the $\alpha$ or $\beta$ families caused a pronounced reduction in IEL chemotaxis to IL- 8 compared with the unexposed control. The greatest inhibition: occurred with IL-8 (89(SD 2)\%), and the least with MCP (54(SD 13)\%).

Secondly, desensitisation to IL-8 was tested음 in the calcium ion mobilisation response. IELs $\frac{\bar{\omega}}{\bar{D}}$

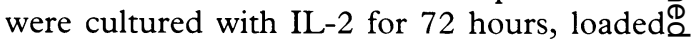
with Fura-2, and then exposed to a chemokine $(1000 \mathrm{nM})$ for 10 minutes. Then the response $\vec{\circ}$ to $1000 \mathrm{nM}$ IL-8 was measured (Fig 4). Again, all five chemokines greatly inhibited IL-8 $\vec{\omega}$ induced calcium influx: IL- 8 had the greatesto inhibitory effect $(89(\mathrm{SD} 7) \%)$, and MCP hadঙ the least (69(SD 17)\%). Thus all five $\stackrel{\circ}{\circ}$ chemokines desensitised IELs to IL-8.

\section{Radioligand binding}

Specific binding of ${ }^{125} \mathrm{I}-\mathrm{IL}-8(10 \mathrm{nM})$ to IELs, $\vec{z}$ LPLs, and PBMCs was measured before and@ after stimulation with IL-2 for 72 hours (Fig) 5). Fresh IELs and LPLs bound much less $\overrightarrow{0}$ IL-8 than did PBMCs $(\mathrm{p}<0 \cdot 05)$. However, IL-2 stimulation more than doubled IL-8 binding to IELs $(p=0.05)$.

The specificity of the receptor for its ligand was determined by the ability of the othero chemokines to compete for binding to the same $\mathbb{D}$ receptor. Radiolabelled IL-8 $(10 \mathrm{nM})$ and $\mathrm{a} \stackrel{2}{\Rightarrow}$ $100 \times$ excess of cold chemokine were added $\frac{0}{3}$ simultaneously and the effect on specific radioligand binding was measured (Fig 6). For IELs, all chemokines tested reduced cell associated radiolabelled IL-8 to a similar extent, suggesting the presence of a promis- $\frac{0}{3}$ cuous receptor on these cells. $T N F \alpha$, by contrast, had no effect on binding of radio- $\frac{0}{3}$ labelled IL-8 to IELs. Binding to LPLs was significantly reduced by the $\alpha$-chemokines, $\rightleftharpoons$

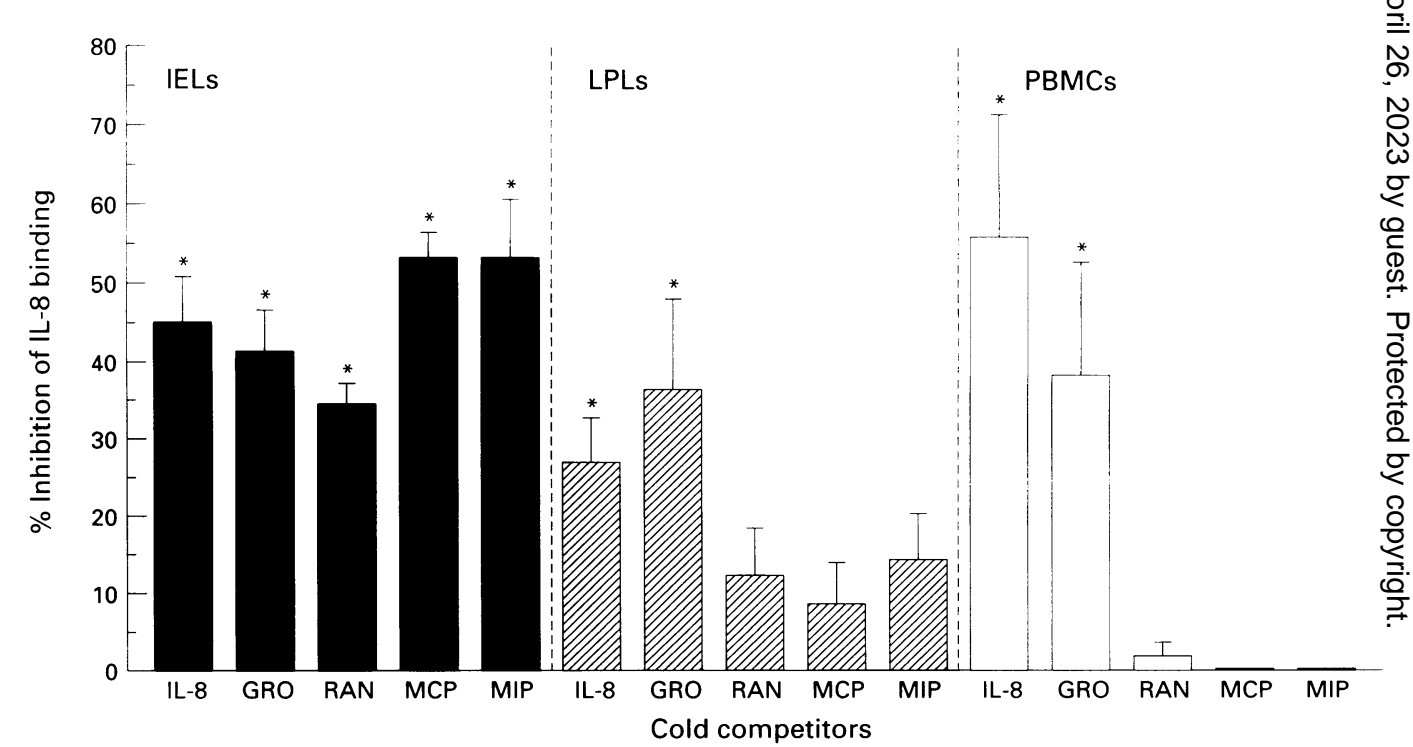

Figure 6: Inhibition of ${ }^{125} I-I L-8$ binding by IELs, LPLs, and PBMCs by unlabelled chemokines (cold competition). Radiolabelled IL-8 (10 nM) with $100 \times$ molar excess of the chemokine were added simultaneously to the binding assay and the decrease in cell bound radioactivity measured and compared with a control with no cold competitor: ${ }^{*} p<0 \cdot 05, n=6$, paired Student's t test. 
whereas $\beta$-chemokines had a smaller effect. This difference was more pronounced for PBMCs: strong inhibition by the $\alpha$-chemokines and no inhibition by the $\beta$-chemokines.

\section{Discussion}

The present study shows that IELs migrate in response to chemokines of both the $\alpha$ and $\beta$ families. They respond better to IL-8, GRO, and RANTES than do LPLs and PBMCs, whereas their responses to MCP and MIP were equal to or less than that of PBMCs. Yet, concurrent calcium ion mobilisation in IELs occurred only with IL-8 and RANTES, but not GRO, MCP, or MIP. Similar results were obtained with PBMCs, whereas LPLs had no calcium mobilisation response to any chemokine. All lymphocytes were first stimulated with IL-2 for 72 hours before each assay as IL-8 binding increases on IELs after this treatment. The degrees of chemotaxis and calcium mobilisation in the present study are similar to those described elsewhere. ${ }^{3}{ }^{13}$ All five chemokines desensitised IELs to subsequent IL-8 stimulated chemotaxis and calcium mobilisation and displaced radiolabelled IL-8 from its receptor on IELs. This interplay of cytokines is suggestive of a common receptor for both $\alpha$ - and $\beta$-chemokines on IELs.

All the chemokines shown here to affect IELs also have effects on peripheral blood T lymphocytes (in addition to their main actions on neutrophils and monocytes). However, the $T$ cell phenotype attracted in peripheral blood often does not match the $\mathrm{CD}^{+} \mathrm{CD} 45 \mathrm{RO}^{+}$ phenotype of IELs. For IL-8, the studies are contradictory: $\mathrm{CD}^{+} \mathrm{T}$ lymphocytes migrate to $\mathrm{IL}-8,{ }^{3}$ but $\mathrm{CD}^{+} \mathrm{T}$ lymphocytes express IL-8 receptors. ${ }^{17}$ GRO attracts $\mathrm{CD} 45 \mathrm{RO}^{+} \mathrm{T}$ lymphocytes of both the $\mathrm{CD}^{+}$and $\mathrm{CD}^{+}$ phenotype, ${ }^{13}$ whereas RANTES draws mainly $\mathrm{CD}^{+} \mathrm{CD}^{2} 5 \mathrm{RO}^{+} \mathrm{T}$ lymphocytes. ${ }^{22}$ All these chemokines attract more IELs than LPLs, indicating that the reactive phenotype in the intestine is not the same one as in peripheral blood. MCP1 is specific for both $\mathrm{CD}^{+}$and $\mathrm{CD}^{+} \mathrm{T}$ lymphocytes of the $\mathrm{CD}^{+} 5 \mathrm{RO}^{+}$ memory phenotype, ${ }^{26}{ }^{27}$ whereas MIP acts mainly on $\mathrm{CD4}^{+} \mathrm{T}$ cells. ${ }^{28}$ Memory cells, which make up most IELs and LPLs, are particularly motile. ${ }^{29}$

Desensitisation experiments showed that all five chemokines nearly eliminated the IL-8 responsiveness of IELs, in both chemotaxis and calcium mobilisation. However, effectiveness in desensitising IELs to IL-8 does not necessarily impart on a chemokine the ability to stimulate them. Indeed, whereas all five chemokines desensitised IELs to IL-8, only IL-8 itself and RANTES induced calcium ion mobilisation; GRO, MIP, and MCP did not. Although most of the increase in $\left[\mathrm{Ca}^{2+}\right]_{i}$ in IELs is due to a release of internally sequestered ions, ${ }^{5}$ the absence of an IL- 8 induced response after pre-exposure to the other chemokines was not due merely to a depletion of internal stores as, in three out of five cases, no internal stores were released in the initial exposure. This lack of correlation between calcium influx and chemotaxis suggests that other processes mediate IEL mobilisation: signalling involving the dissociation of $G$ proteins and desensitisation involving phosphorylation of $\mathrm{C}$ terminal cytoplasmic residues on $\mathrm{G}$ protein linked receptors. ${ }^{14}$

The ability of chemokines to modulate IL-8 responsiveness could be due to heterologous desensitisation rather than direct competition with the IL-8 receptor. However, inhibition of IL-8 binding to the cell by chemokines of both the $\alpha$ and $\beta$ families suggests that the IL- 8 receptor is promiscuous. MCP offered the least desensitisation, perhaps due to an imperfect fit with the IL-8 receptor. By contrast, IL-8 and GRO were the only chemokines able to compete for the PBMC IL-8 receptor. The IEL receptor binds a broader range of chemokines than even the erythrocyte receptor in that it binds MIP as well as IL-8, GRO, RANTES, and MCP. Unfortunately, low specific binding precluded a more quantitative analysis of receptors, but differences in specific binding in the presence or absence of competition by other chemokines were still clearly discernable. In agreement with this finding, IL-8 receptors have been found to be on only a small fraction of $\mathrm{T}$ lymphocytes $(5 \%-25 \%)^{17}$ and at low density. ${ }^{13}$ One group, however, was able to estimate that 1200 to 2600 IL-8 receptors were found on each lymphocyte with a Kd of 0.55 $\mathrm{nM} .^{3}$ If this large a receptor number had been present on IELs, it would have been detected by the technique used in our laboratory. ${ }^{24}$

It is surprising that more IELs than LPLs respond to chemokines, given the greater $\mathrm{T}$ cell responsiveness of LPLs, particularly in proliferation and the production of proinflammatory cytokines. ${ }^{30}$ This finding is consistent with the idea that $T$ cells destined to become IELs reside in the lamina propria and, when given the appropriate stimulus, traverse the basement membrane and enter the epithelium, particularly during injury to the epithelium. Epithelial cells do secrete IL-8, MCP, and probably other IEL chemoattractants in response to injury such as bacterial invasion and stimulation by $\mathrm{TNF} \alpha$ or IL-1. ${ }^{8-12}{ }^{31}$ IELs may migrate towards the epithelium in response to any of these chemokines. In fact, IL-8 production is in the $\mathrm{ng} / \mathrm{ml}$ range, certainly enough to affect IELs. It may be by this mechanism that IEL numbers increase in diseases in which the initial insult is to the epithelium - for example, coeliac sprue, giardiasis, cow's milk allergy, and tropical sprue. The IELs may then lyse the injured epithelial cells in a manner similar to their destruction of colon cancer cells, ${ }^{32}$ resulting in a loss of surface epithelium and the shortened villi found in these diseases.

This work was supported by a grant from the National Institutes of Health (DK42166). It has appeared in part in abstract form as Ebert EC, Roberts AI. The promiscuity of interleukin-8 receptors on human intraepithelial lymphocytes. Gastroenterology 1996; 110: A901.

1 Djeu JY, Matsushima K, Oppenheim JJ, Shiotsuki K, Blanchard DK Functional activation of human neutrophils by recombinant monocyte-derived neutrophil chemotactic factor/IL-8. F Immunol 1990; 144: 2205-10. 
2 Krieger M, Brunner T, Bischoff SC, von Tscharner V, Waltz A, Moser B, et al. Activation of human basophils through the IL-8 receptor. $\mathcal{F}$ Immunol 1992; 149: 2662-7.

3 Bacon KB, Flores-Romo L, Life PF, Taub DD Premack BA, Arkinstall SJ, et al. IL-8-induced signal transduction in $T$ lymphocytes involves receptormediated activation of phos

Sebok K, Woodside D, Al-Aoukaty A, Ho AD, Gluck S, Maghazachi AA. IL-8 induces the locomotion of human IL-2-activated natural killer cells. $f$ Immunol 1993; 150: 1524-34.

5 Ebert EC. Human intestinal intraepithelial lymphocytes have potent chemotactic activity. Gastroenterology 1995 150: 1154-9.

6 Ebert EC, Roberts AI, Brolin RE. GRO is chemotactic for human intestinal intraepithelial lymphocytes. Inflammatory Bowel Diseases 1995; 1: 179-83.

7 Thornton AJ, Strieter RM, Lindley I, Baggiolini M, Kunkel SL. Cytokine-induced gene expression of a neutrophil chemotactic factor/IL-8 in human hepatoneutrophil chemotactic factor/IL-8
cytes. $\Im$ Immunol 1990; 144: 2609-13.

8 McCormick BA, Colgan SP, Delp-Archer C, Miller SI Madara JL. Salmonella typhimurium attachment of human intestinal epithelial monolayers: transcellula signalling to subepithelial neutrophils. F Cell Biol 1993; 123: 895-907.

9 Schuerer-Maly C-C, Eckman L, Kagnoff MF, Falco MT, Maly F-E. Colonic epithelial cell lines as a source of interleukin-8: stimulation by inflammatory cytokines and bacterial lipopolysaccharide. Immunology 1994; 81: 85-91.

10 Lammers KM, Jansen J, Bijlsma PB, Ceska M, Tytgat GNJ, Laboisse CL, van Deventer SJH. Polarised interleukin 8 secretion by HT29/19A cells. Gut 1994; 35: 338-42.

11 Gross V, Andus T, Daig R, Aschenbrenner E, Scholmerich J, Falk W. Regulation of interleukin-8 production in a human colon epithelial cell line (HT-29). Gastroenterology 1995; 108: 653-61.

12 Crowe SE, Alvarez L, Dytoc M, Hunt RH, Muller M, Sherman $\mathrm{P}$, et al. Expression of interleukin 8 and CD54 by human gastric epithelium after Helicobacter pylori infection in vitro. Gastroenterology 1995; 108: 65-74.

13 Jinquan T, Frydenberg J, Mukaida N, Bonde J, Larsen CG, Matsushima K, Thestrup-Pedersen K. Recombinant human growth-regulated oncogene- $\alpha$ induces T lymphocyte chemotaxis. F Immunol 1995; 155: 5359-68.

14 Horuk R. The interleukin-8-receptor family: from chemokines to malaria. Immunol Today 1994; 15: 169-74.

15 Lee J, Horuk R, Rice GC, Bennett GL, Camerato T, Wood WI. Characterization of two high affinity human interleukin-8 receptors. $¥$ Biol Chem 1992; 267: 16283-7.

16 Holmes WE, Lee J, Kuang W-J, Rice GC, Wood WI. Structure and functional expression of a human Structure and functional expression of a hu

17 Chuntharapai A, Lee J, Hebert CA, Kim KJ. Monoclonal antibodies detect different distribution patterns of IL-8 receptor A and IL-8 receptor B on human peripheral blood leukocytes. F Immunol 1994; 153: 5682-8.

18 Van Riper G, Siciliano S, Fischer PA, Meurer R, Springer MS, Rosen H. Characterization and species distribution of high affinity GTP-coupled receptors for human RANTES and monocyte chemoattractant protein 1. $\mathcal{F}$ Exp Med 1993; 177: 851-6.

19 Yoshimura T, Leonard E. Identification of high affinity receptors for human MCP-1 on human monocytes. $F$ Immunol 1990; 145: 292-7.

20 Darbonne WC, Rice GC Mohler MA, Apple T, Hebert CA, Valente AJ, Baker JB. Red blood cells are $\mathrm{a}=$ sink for interleukin 8, a leukocyte chemotaxin. $f$ Clin Invest 1991; 88: 1362-9.

21 Neote $K$, Darbonne W, Ogez J, Horuk R, Schall TJ. O Identification of a promiscuous inflammatory peptide $\bar{C}$ receptor on the surface of red blood cells. $\mathcal{f}$ Biol Chem $\overline{\bar{c}}$ 1993; 268: 12247-9.

22 Schall TJ, Bacon K, Toy KJ, Geoddel DV. Selective $\mathbb{\Phi}$ attraction of monocytes and T lymphocytes of the
memory phenotype by cytokine RANTES. Nature 1990; 347: 669-71.

23 Roberts AI, Taunk J, Ebert EC. Human lymphocytes lack $\vec{\circ}$ substance $P$ receptors. Cell Immunol 1992; 141: 457-65.

24 Roberts AI, Panja A, Brolin RE, Ebert EC. Human $\vec{\omega}$ intraepithelial lymphocytes - Immunomodulation and receptor binding of vasoactive intestinal peptide. Dig Divo Sci 1991; 36: 341-6.

25 Roberts AI, Leone VM, Ebert EC. Intestinal mucosal lymphocytes have $H_{1}$ receptors: $H_{1}$ antagonists reduce $O$ their proliferation and cytotoxicity. Cell Immunol 1994; $\omega$ 156: 212-9.

26 Taub DD, Proost P, Murphy WJ, Anver M, Longo DL, w్ట Van Damme J, Oppenheim JJ. Monocyte chemotactic protein-1 (MCP-1), -2 and -3 are chemotactic for human protein-1 (MCP-1), 2 and -3 are chemotactic

27 Carr MW, Roth SJ, Luther E, Rose SS, Springer TA. Monocyte chemoattractant protein 1 acts as as T-lymphocyte chemoattractant. Proc Natl Acad Sci 1994; 91: 3652-6.

28 Schall TJ, Bacon K, Camp RDR, Kaspari JW, Goeddel DV. Human macrophage inflammatory protein $\alpha$ (MIP-1 $\alpha)$ and MIP-1 $\beta$ chemokines attract distinct populations ofe
lymphocytes. $\mathcal{F}$ Exp Med 1993; 177: 1821-5.

29 Newman I, Wilkinson PC. Locomotor responses of human CD45 lymphocyte subsets: preferential locomotion of CD45 $\mathrm{RO}^{+}$lymphocytes in response to attractants and mitogens. Immunology 1993; 78: 92-8.

30 Ebert EC. Proliferative responses of human intraepithelialo lymphocytes to various T-cell stimuli. Gastroenterologyo 1989; 97: 1372-81.

31 Reinecker H-C, Loh EY, Ringler DJ, Mehta A, Rombeau JL, MacDermott RP. Monocyte-chemoattractant protein $1 \bar{O}$ gene expression in intestinal epithelial cells and 3 inflammatory bowel disease mucosa. Gastroenterology 1995; 108: 40-50.

32 Roberts AI, O'Connell SM, Ebert EC. Intestinal intra-O epithelial lymphocytes bind to colon cancer cells by epithelial lymphocytes bind to colon cancer cells 